REVIEW OF HISTORICAL SCIENCES 2017, VOL. XVI, NO. 3

http://dx.doi.org/10.18778/1644-857X.16.03.05

Ewelina Maria Kostrzewska

UnIVERSity OF LODZ*

\title{
A reportage at the end of the century European economic journeys of Countess Cecylia Plater-Zyberk in the light of the "Kronika Rodzinna" (1899)
}

Summary. The article was prepared on the basis of the "Kronika Rodzinna", a biweekly published from 1867 in Warsaw. It was addressed to the gentry and intelligentsia, had a literary-social, as well as diary-travel character and often described the so-called feminine issues. During its existence there were program changes. After ideological disputes of the eighties of the $19^{\text {th }}$ century, editors focused on matters related to the household and education. As they followed a moderate mainstream movement of women, the professional education and activity of the latter were promoted by them.

In 1899, Countess Cecylia Plater-Zyberk became the chief editor and the publisher of the magazine. She assimilated landowners', conservative ideals with an intelligent model of an open Catholicism. During an almost one-year of her cadency, the "Kronika Rodzinna" was transformed into a popular "Czasopismo dla Rodzin Katolickich". The editor herself inaugurated and ended her functions in a series of travel reports.

Using such a modern form of journalistic report, she entered the hard-to-reach for women world of media, professional work, as well as of independent fast travels. While bringing to the common denominator the search for female economic schools in Europe, she was reporting on their civilizational condition. In the descriptions saturated with religious axiology, she presented the readers with her own reflections and social contexts of women's emancipation.

In a travel reportage she returned to the Polish ground with an idea of a social solidarity; a reconciliation of women's aspirations with religion. The social bond was to join in a special way women from the landowners' elites and peasant villages, while economic schools were to open to them fields of different activities

* The Faculty of Philosophy and History, The Institute of History, The Department of History of Poland of $19^{\text {th }}$ Century / Wydział Filozoficzno-Historyczny, Instytut Historii, Katedra Historii Polski XIX w., e-mail: ewekostrzewska@o2.pl. 
and work. According to the rules of a press reportage, the story of Plater-Zyberk revealed the European reality of the late $19^{\text {th }}$ century in her subjective images seen from the perspective of an aristocrat and the chief-editor of the Catholic "Kronika Rodzinna".

Keywords: Catholic magazines, "Kronika Rodzinna", reportage, Countess Cecylia Plater-Zyberk, the Kingdom of Poland's press, travel, economic schools, Europe.

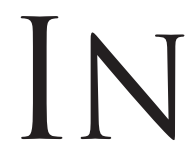
the European culture a reportage, as a separate writing phenomenon, grew out of $18^{\text {th }}$-century journey's descriptions disseminated in the press. Its climax in the next century was coincident with civilizational changes that gave a new quality and speed to the circulation of information, as well as the covering of distance.

At the end of the $19^{\text {th }}$ century the importance of a reportage had increased in the Polish press, too ${ }^{1}$. When communication developed, it gained the rank of a modern medium of communication ${ }^{2}$. More and more often that type of writing, which was joining elements of journalistic information, journalism and literature, was used by women. Reports from independent travels around the world became a fashionable trend and a symptom of emancipation. Earlier elite's phenomenon of the Grand Tour, along with the development of tourism, took the form of shorter, task-oriented reporting trips. They were often accompanied by a context of cultural education, reinforced by characteristics reserved for a reportage, namely authenticity, dynamism and timeliness of events, as well as importance of problems known to the authors from their own experiences.

Countess Cecylia Plater-Zyberk (1853-1920), a known journalist, a prominent pedagogue and a founder of female vocational schools in the Kingdom of Poland, started such a reporting journey in $1898^{3}$. A member of a hidden movement of religious congregations created by Capuchin Honorat Koźmiński (1829-1916) published her travel account of 1899 in the "Kronika Rodzinna" which was favoring religious values.

\footnotetext{
${ }^{1}$ M. Wojtak, Gatunki prasowe, Lublin 2004, p. 268 and the following.

2 See A. Mattelart, M. Mattelart, Teoria komunikowania, Warszawa 2001.

3 T. Górs ki, Plater-Zyberk Cecylia, [in:] Polski słownik biograficzny, vol. XXVI, Kraków 1981, pp. 693-694.

${ }^{4}$ M.H. Mazurek, Powstanie i rozwój ukrytych zgromadzeń bł. Honorata Koźmińskiego w latach 1874-1908, Sandomierz 2009.
} 
The magazine had already had a long publishing tradition with programmatic transformations. It was founded in 1867 by Aleksandra Borkowska and it was a biweekly addressed to the gentry and intelligentsia. It often described the so-called feminine issues and had a literary-social, as well as diary-travel character ${ }^{5}$. In 1873, the "Kronika Rodzinna" was taken over by activists of the former Agricultural Society, Adam Goltz and Ludwik Górski. In its polemics with the young press of the positivists, the magazine was becoming more and more religious ${ }^{6}$. It perceived the family as a mainstay of the landowner's family tradition, in which a woman was seen as a home's guardian and socio-economic activist. After ideological disputes, from 1880, editors who sympathized with an enlightened conservatism started to cultivate literary interests. At the same time they focused on the household and educational matters. As they followed a moderate mainstream movement of women, the professional education and activity of the latter were promoted by them. Such a programmatic view survived after 1896, when the "Kronika Rodzinna" was edited by Priest Marceli Godlewski. As a supporter of a doctrine of social Catholicism, he directed the periodical towards the Christian democracy. In January 1899, in the face of problems with a censorship, he entrusted the function of periodical's chief-editor and publisher with Miss Plater-Zyberk, who assimilated landowners', conservative ideals with an intelligent model of an open Catholicism. During an almost one-year of her cadency, the "Kronika Rodzinna" was transformed into a popular "Czasopismo dla Rodzin Katolickich". As a chief-editor, she became a member of rather small group of women from the media circle who were fighting with reluctance of the public opinion and together with men were gaining the status of publicists, writers and sometimes even journalists ${ }^{7}$.

It is significant that Miss Plater-Zyberk's promotion in an editorial office of the "Kronika Rodzinna" was inaugurated and closed by a travel reportage printed in episodes. She emphasized the reporting, task-oriented character of her trip by referencing to the idea

\footnotetext{
${ }^{5}$ M. Sikors ka-Kow als ka, Kwestia kobieca $w$ świetle programu społecznego “Kroniki Rodzinnej” Aleksandry Borkowskiej (1867-1872), "Acta Universitatis Lodziensis", Folia Historica 61, 1998, pp. 17-32.

${ }^{6}$ B. Le sis $z$, Polskie czasopisma religijno-społeczne $w$ XIX w., Warszawa 1988, pp. 305-306.

7 See Kobieta i media. Studia z dziejów emancypacji kobiet, eds P. Perkowski, T. Stegner, Gdańsk 2009.
} 
that "Well thought travels have always excellently contributed to the progress" 8 . The aristocrat, who was grown up in an ancestral tradition of the northern Kurdish borderlands in a multiethnic and religiously diverse culture, identified that progress with the most urgent need to increase religious, social and economic standards of Poles' lives to the level of a modern civilization from the West. She knew it well, as she belonged to the elite for which travels around the world were rooted in an environmental specifics ${ }^{9}$. Traveling passions accompanied the countess from her early youth, when she and her family traveled around Europe and partitioned districts where residences and estates of the Plater-Zyberk family were located. Her knowledge and observations on civilizational differences of that time were used in her educational activity, as in 1891 she created the female School of Life Sciences in Chyliczki near Warsaw ${ }^{10}$.

On July 17, 1898, accompanied by the superior of that institution, the future chief-editor of the "Kronika Rodzinna" set off from Chyliczki for an over three week long trip around Central and Western Europe through the Grand Duchy of Poznan, Germany, France and the Czech Kingdom (Bohemia) ${ }^{11}$. Women who set off on that independent journey had been friends for a very long time, as they were running the aforementioned school together. Miss Felicja, invoked in the press story only by name, was responsible for the economic nature of the school ${ }^{12}$. Education and matters of religion were the responsibility of Miss Plater-Zyberk, who also acted as a mentor in an expedition on the European routes. The main thought behind that trip was, in addition to the general idea of tracking progress, to look for economic schools for girls.

8 Wrażenia z wycieczki gospodarczej po ks. Poznańskiem, Niemczech, Francji, Czechach. Cel podróży - Dobrojewo - Borejowice [properly Bożejowice], "Kronika Rodzinna" [further on: KR] 1899, No. 1, p. 15.

${ }^{9}$ See Ziemiaństwo na Lubelszczyźnie IV. Ziemianie $w$ podróży, vol. I-II, ed. H. Łaszkiewicz, Lublin 2010.

10 E.M. Kostrzewska, Szkolnictwo gospodarczo-rolnicze ziemianek Królestwa Polskiego na przełomie XIX $i$ XX w. Między tradycja a nowoczesnościa, [in:] $Z$ dziejów polskiej kultury i oświaty od średniowiecza do początków XX wieku, eds K. Jakubiak, T. Maliszewski, Kraków 2010, p. 152 and the following.

11 Wrażenia z wycieczki gospodarczej po ks. Poznańskiem..., pp. 15-18.

12 With Miss Plater-Zyberk traveled Felicja Czyż who, similarly to the countess, belonged to the non-frock assembly of the Sisters of the Messengers. Józefa Chudzyńska, the superior of the congregation, paid a lot of attention to her involvement in the school's economic work. The Archives of the Messengers in Konstancin-Jeziorna, no reference number, J. Chudzyńs ka, Pamiętnik, pp. 207-211. 
Women's vocational education related to their activation on the labor market, especially from the second half of the $19^{\text {th }}$ century, was an inflammatory and civilizational challenge of the era. At the end of the century, better educated women were pouring into new professions previously reserved only to men ${ }^{13}$. Women from agriculture also joined them, as economic schools were to teach them of modern thinking about housewives and rural work. Miss Plater-Zyberk's plan was to diagnose their situation and confront that type of foreign institutions with Chyliczki. The traveler began her description with a report from a week's stay in the Grand Duchy of Poznań.

The agriculture of that partitioned district was a synonym of the modernity and civilizational progress. The Greater Poland's landowners and some part of aristocracy belonged to the best prepared farmers, who could compete even with the greatest landowners of Western Europe. They were striving to preserve a hegemonic position in the Polish society and to effectively compete for the land with the German element, thus they were modernizing their estates and adopted a lifestyle of the socialized "gentleman of farmers"14. Women, including aristocrats, were also involved in economic and social work $^{15}$. Barbara Kwilecka of the Mańkowski family was famous in all three partitioned districts because of her economic school for peasant daughters in Dobrojewo ${ }^{16}$. Her estate was the first point on the route of Miss Plater-Zyberk. She was hosted in the school owner's palace as a person who belonged to a part of the world of its inhabitants, but at the same time she came from the outside and from such a double perspective she described the situation and her own impressions on the visited school. The way common girls were raised in a spirit of a Catholic social solidarism giving them basics of knowledge of reading, writing and bills aroused her enthusiasm.

${ }^{13}$ Z. Chyra-Rolicz, Pionierki $w$ nowych zawodach na poczatku XX wieku, [in:] Kobieta $i$ edukacja na ziemiach polskich $w$ XIX $i$ XX $w$. Zbiór studiów, vol. II, part 2, eds A. Żarnowska, A. Szwarc, Warszawa 1992, pp. 221-236.

${ }^{14}$ W. Molik, Przekształcanie sie wielkopolskiego szlachcica $w$ ziemianina - uspolecznionego farmera $w$ XIX i na poczatku XX w., [in:] Ziemiaństwo wielkopolskie. W kręgu arystokracji, ed. A. Kwilecki, Poznań 2004, pp. 24-26.

${ }^{15}$ Idem, Ziemianki wielkopolskie $w$ codziennych zajeciach gospodarczych $i w$ pracy społecznej $w$ drugiej połowie XIX $i$ na poczatku XX wieku, [in:] Kobieta i kultura życia codziennego wiek XIX i XX. Zbiór studiów, vol. V, eds A. Żarnowska, A. Szwarc, Warszawa 1997, pp. 181-190.

16 D. Kamiński, Barbara z Mańkowskich Kwilecka-wybitna Wielkopolanka, "Wiadomości Ziemiańskie" 2017, No. 71, pp. 82-88. 
She admired the way they were being prepared for professional duties of domestic and court service, as well as the fact that girls were called apprentices and were wearing the unified attire. On the one hand, white bonnets and aprons symbolized the prestige of being taught by the countess, on the other, they were to provide double protection: against demoralization from men employed in the palace and from excessive social aspirations. Thus, uniforms of apprentices were to preserve their self-identification with the paid service. Under the guidance of servants of a higher rank girls had three years of apprenticeships in the kitchen, pantry, laundry room or courtyard farm. Thus, according to Miss Plater-Zyberk, the teaching standards in Dobrojewo, though worth of popularization, differed from the standards of a real school.

The authoress also examined goods in Dobrojewo and nearby Oporów. While describing with a reporter's accuracy farm buildings, she did not hide her fascination with the "male farm". She also did not hide the "desire" to have equally beautiful swine or cattle in Chyliczki. As she wrote: "every cow, washed and shredded every day, shone like a horse" 17 .

In a different context, referring to the Dobrojewo landowner's problems with employing qualified servants and economic officials, she described the exemplary poultry breeding of Helena Potworowska from Bożejewice ${ }^{18}$. The modernity and openness of the chicken farm's owner who was making use of foreign technical innovations could have been an example for women from aristocratic and landowner's circles who were entering the field of economic successes with the most profitable domains: poultry and dairy ${ }^{19}$. At the same time, the traveler wanted to find out whether a popular opinion that German schools had a great impact on the professionalization of women's work in a rural farm was true. Miss Plater-Zyberk summed up her unsuccessful attempts to obtain from the Greater Poland's aristocrats information on that issue with those words: "Dark everywhere, quiet everywhere. What shall it be! What shall it be!"20.

17 Wrażenia $z$ wycieczki gospodarczej po ks. Poznańskiem, Niemczech, Francji, Czechach. Dalszy ciag, KR 1899, No. 2, p. 46.

18 Ibidem, pp. 47-48.

19 E.M. Kostrzewska, Ziemianki Królestwa Polskiego a gospodarka. Koncepcje i empiria (przełom wieków XIX i XX), "Studia Maritima” [Szczecin] 2015, vol. XXVIII, eds Z. Anusik, R. Gaziński, pp. 295-315.

20 Wrażenia z wycieczki gospodarczej..., p. 46. 
However, that determined and stubborn tracker of the modernity decided to solve the mystery.

The first step was to reach the Polish school in Śrem ${ }^{21}$. She previously obtained information on the subject in Warsaw, which allowed to present the school in the "collection of economic pictures" ${ }^{22}$. The short road to Srem was a torment. The train moved at a speed arousing temptation to shout, as on a "lame nag: Ho, geep up, geep up, geep up!!!"23. The school did not live up to expectations. It was founded and run by Felicjanna Szczerbińska and it turned out to be an educational institution with an annual household course. The school's brand was saved thanks to a good level of practical classes, religious and patriotic education, care for the health and hygiene of students. Its main disadvantage was the resignation from classes on a rural farm running, which was caused by the lack of financial resources and no interest of students. Miss Plater-Zyberk perceived it through the prism of the specificity of the Prussian partition, where it was customary that girls' education should give them general knowledge. She also noticed capitalist changes in the Greater Poland's agriculture to which women could not adapt their own aspirations and entrepreneurship. Classes on running the household were limited in Srem to teaching the ability how to meet the family's needs. They did not give the professional status and did not prepare for paid jobs. Governmental German schools in Poznan were much better in that regard. As they were well equipped, they may be called schools of the $20^{\text {th }}$ century.

The next stage of Miss Plater-Zyberk's journey was Berlin. "On July 23, we started our trip for good. We left Poznan for Berlin at 4 o'clock in the afternoon [...]. I knew Berlin well, I visited it many times, it was no attraction for me", wrote the traveler ${ }^{24}$. From the capital of Germany, the traveler set off to Hanover, omitting Hamburg with its famous modern poultry farms. The recommended hotel turned out to be "a big hut a bit refreshed" 25 . With the

\footnotetext{
${ }^{21}$ Dzieje Śremu, ed. S. Chmielewski, Warszawa-Poznań 1972, pp. 226-227.

22 Wrażenia z wycieczki gospodarczej po ks. Poznańskiem, Niemczech, Francji, Czechach. Dalszy ciag, KR 1899, No. 3, p. 83.

${ }^{23}$ Ibidem.

${ }^{24}$ Wrażenia z wycieczki gospodarczej po ks. Poznańskiem, Niemczech, Francji, Czechach przez C.P.Z. Dalszy ciag. Hanower. Hodowla drobiu, mleczarnia, KR 1899, No. 5, pp. 147-148.
}

${ }^{25}$ Ibidem, p. 148. 
greatest difficulty both Poles obtained the address of a poultry farm known in the city. After a long-lasting journey, Miss Plater-Zyberk finally reached hen houses she was interested in. Negotiations with their owner ended with a purchase of hens and roosters which were to be transported to Chyliczki. As successful transaction was made in Hannover, previous plans to travel to France were abandoned. After the aforementioned transaction and a visit to a dairy, Hanover had nothing more to offer to Polish travelers. Thus, they quickly set out a new point of their expedition which was an economic school for girls in Alzay near Mainz ${ }^{26}$.

Contrary to expectations, the institution turned out to be a standard household school. It had a similar model of education as a school in Śrem, and although it had only 20 schoolgirls, its financial situation was good, as it was guaranteed by the state, local governments and student donations. In comparison to Chyliczki, depicted by Miss Plater-Zyberk as a modern, self-financed rural farm, the school in Alzey stacked up, though.

Despite an impressive residence in a spacious tenement house with fountains, perfect canalization in dairies, as well as glazed cheese dairies and enviable kitchen equipment, the occupation of girls within five months of learning was limited to cooking, sewing, washing, making cheese, butter and preserves. An undoubted advantage of that institution was the teaching of basics of accounting, which could help in the future organization of the household budget. Practical classes, however, dominated, and their prose in Miss Plater-Zyberk's view was deepened by the chilly atmosphere of the Protestantism which was causing that "everything here revolves only around the earth and for the earth" 27 . The Protestantism was teaching the Christian morality, but was depreciating feelings.

A dominant feature of girls' lifestyle and work was bourgeoiseness. Students made an unpleasant impression. On heavy silhouettes of common girls middle-class dresses "with falling tails and frills", unprotected by aprons, looked pretentious. They were unhygienic and trashy. The grotesque character of them was sharpened by a comparison with navy blue, canvas school uniforms and white aprons of girls from Chyliczki.

${ }^{26}$ Wrażenia z wycieczki gospodarczej po ks. Poznańskiem, Niemczech, Francji, Czechach przez C.P.Z. Szkoła gospodarcza w Alzay pod Moguncja, KR 1899, No. 7, p. 227.

${ }^{27}$ Wrażenia z wycieczki gospodarczej po ks. Poznańskiem, Niemczech, Francji, Czechach przez C.P.Z. (Dalszy ciag), KR 1899, No. 8, p. 256. 
German middle-class civilization was also responsible for the appearance of the residential part of the school, especially the girls' bedroom with "red eiderdowns" on beds. The motif was underlined by the Polish aristocrat throughout all her travel. The school in Alzay was a key point on Miss Plater-Zyberk's route. Thanks to the interviews with the director and the school community it was clear that in the Rhineland, among many similar institutions, the school was regarded as a "star and model" 28 . Girls from Alzay sang cantatas $O, D u$ theures Vaterland (About the love of the homeland) for the leaving Polish travelers, which was a symbolic chord.

Next stages of the authoress's journey were an occasion to comment on the world of the industrial-urban Western civilization. Its expansion, in the eyes of Miss Plater-Zyberk, ruined the rural landscape. Houses and tenements occupied that space, they were part of the city which moved outside. A confluent landscape blurred social differences which disturbed the inherent order of things. Common people had the right to justice, education and work. Social hierarchy and harmony, Christian customs and rural simplicity of life, namely things that should be brought up by school and education, should be preserved. However, it was not an easy task, as it was evidenced by some of Chyliczki's students who aspired for an urban lifestyle. As Miss Plater-Zyberk wrote, they were ready to put on hats and "tulle on their mouth" 29.

It raised the question, whether one may find a school that, while giving knowledge and expertise, would help schoolgirls to preserve the social order and attachment to rural life. Such a hope was raised by Mainz, where Polish travelers were sent to schools run by female religious congregations that once again became popular in Germany. The largest applause of the seeker of an ideal school was aroused by the "Haus haltung schule" which was educating girls from good families ${ }^{30}$. When describing the institution, Miss Plater-Zyberk underlined its originality. In a complex of buildings occupied by the monastery and school, a ground floor was a guesthouse with apartments for wealthy tourists. In such a way an elite,

\footnotetext{
${ }^{28}$ Ibidem.

${ }^{29}$ Ibidem, p. 259.

30 Wrażenia z wycieczki gospodarczej po ks. Poznańskiem, Niemczech, Francji, Czechach przez C.P.Z. (Dalszy ciag). Moguncja, KR 1899, No. 9, pp. 289-291; Wrażenia z wycieczki gospodarczej po ks. Poznańskiem, Niemczech, Francji, Czechach przez C.P.Z. (Dalszy ciag), KR 1899, No. 10, pp. 328-331. In modern translation it means: School of cleaning and nutrition; in Germany schools of that type still exist.
} 
emancipated world of women was created in the suburban garden district unavailable to men.

The guesthouse managed by students, according to Miss Plater-Zyberk, could provide internships to girls preparing for service. But the school did not set itself such goals. Its goal was the Catholic upbringing and education in the field of a modern household without professional certifications. The program was carried out in comfortable five kitchen rooms, spacious lecture rooms, a dining room and student's bedroom. The institution, equipped with central heating, bathrooms, wardrobes and laundries, impressed with aesthetics and order. When crossing the thresholds of the school, travelers felt as in a familiar place "where everything breathed the love of God and people"31. According to Miss Plater-Zyberk, those values should be shared by entire civilized Europe. Nuns combined the affirmation of religion with the pragmatism of work and talent of managers. Polish travelers benefited from those advantages and quickly moved from the hotel to the school's guesthouse, not hiding an intention of its promotion. A few columns of print devoted to the description of interiors and advantages of the school and the guesthouse were also a story about European exclusive hotel kitchens, which did not equal the quality of luxury catering served at the Mainz institution ${ }^{32}$. On that occasion, the founder of Chyliczki did not hesitate to advertise a health food store run by the institution ${ }^{33}$.

The shopping in the fashion store and a strong criticism of the city's dairy with its anti-hygienic conditions closed the stay in Mainz. The ending of the German stage of the journey was also approaching, as a further plan envisaged to travel through Frankfurt and Leipzig to Prague. During her journey to the capital of the Czech Kingdom, Miss Plater-Zyberk was pondering about the encyclical Rerum Novarum, in which there were included ideas of the social Catholicism, as well as a strong criticism of the capitalist exploitation. The authoress of the reportage concluded her travel reflections on the subject with those words: "It is easy for me, from the distance, travelling comfortably in a car, to solve intricate social issues on which economists have been thinking about intensively" 34 .

31 Wrażenia z wycieczki gospodarczej..., No. 10, p. 329.

${ }^{32}$ Wrażenia z wycieczki gospodarczej..., No. 9, p. 290.

${ }^{33}$ Wrażenia z wycieczki gospodarczej..., No. 10, p. 330.

34 Wrażenia z wycieczki gospodarczej po ks. Poznańskiem, Niemczech, Francji, Czechach przez C.P.Z. (Dalszy ciag), KR 1899, No. 11, p. 365. 
The countess suggested a Christian-social principle: a fair pay for an honest work.

As Polish travelers did not find anything interesting in the surroundings of Frankfurt and Leipzig, Miss Plater-Zyberk filled up their five-hour waiting time for the train to Prague with memories from her earlier trips to Paris and Linz. The first retrospection described a short trip in the spring of 1894 to the only one at the time government school of raising of poultry that was located nearby the capital of France ${ }^{35}$. "Taking the fastest train and driving without a break" the authoress of the reportage reached Paris, from where she spent a further route to Gambais Houdan in a company of Countess Jadwiga Zamoyska, the creator of a school of the household that was ideologically close to Chyliczki. It was founded in 1882 in Kórnik, but after Prussian repressions it was transferred to Kuźnice near Zakopane ${ }^{36}$. The purpose of the trip was to discover reasons for the failure of an incubator that had been previously bought at that school. That achievement of civilization was destroying the poultry farm in Chyliczki. Inquisitive aristocrats discovered that the reason was a deliberately concealed technical glitch of a device. Thus, they observed the school with reserve. Lack of hygiene, diligence or humanitarianism in the treatment of birds - those were its main sins. Hen houses transformed into guest rooms, terrible food, arrogance of the management, insubordinate service were its shortcomings, too. A serious drawback was also a co-education, that was threatening, according to Polish aristocrats, morality by a too liberal upbringing. The next stage of the journey was Mantes where the poultry farm and incubators' factory were located. An incubator and specimens of birds purchased there were taken on the return journey to Poland. In Chyliczki a defected old incubator was burned and its tasks were successfully fulfilled by a new device bought in a specialized plant.

The promotion of technical culture was one of the main tasks of economic schools and a goal of the reported journey. Therefore, the authoress introduced in her retrospective story a report on achievements of another school which she visited in December

${ }^{35}$ Paryż i jego okolice (Z wycieczki gospodarczej) przez C.P.Z., KR 1899, No. 13, pp. 435-440.

${ }^{36}$ K. Czachow ska, Generałowa Jadwiga Zamoyska (1831-1923). Życie i dzieło, Poznań 2011, p. 233 and the following. 
$1895^{37}$. Through Vienna and Linz she reached Mittelsbach. The town was located in the Tyrolean mountains and distinguished itself with a girls' economic enterprise founded in 1889 and run by nuns from the Franciscan congregation. The school supervised by state authorities did not arouse Miss Plater-Zyberk's enthusiasm, though. As in most of the described schools, the emphasis was put there on the household. A farm was managed by a separate housekeeper. It was: "A strong woman, like a Kurland's oven, who could be a match to two men" 38 , but who did not pay too much attention to her teaching duties. Girls were brought up in the spirit of German order, as they were constantly cleaning well-equipped living and utility rooms. The school was positively distinguished by an atmosphere of deep religiosity and contemplation instilled in the students, which clearly contrasted with students' cries of the coeducational French school. The authoress described experiences obtained during her earlier trips as "a real steeple-chasse with obstacles"39.

The country she was approaching, namely the Czech Kingdom ruled by the Habsburgs, was characterized by the organism's model of progress in agriculture which aroused a keen interest of the Greater Poland's community, also due to the similarities in the fight against the Germanisation. Miss Plater-Zyberk stated that her stay in the Czech Kingdom was the climax of her expedition and she appealed to the general opinion about the unique contribution of women to the development of the Czech civilization ${ }^{40}$. Prague was her target point from which she intended to "ride on the right and on the left" with Miss Felicja ${ }^{41}$.

The first impression was not optimistic. A clean women's compartment in a German train was changed to a Czech wagon, which meant a journey in tobacco smoke and uninteresting company. The "Royal" hotel traditionally turned out to be an "old shack". At the same time, the Czech wanderings ceased to be, as before, a rush into the unknown. They became planned trips with the school register provided by a professional information office for farmers.

${ }^{37} \mathrm{Na}$ stoku gór tyrolskich. Obronny zameczek pod Linzem. (Z wycieczki gospodarczej) napisała C.P.Z., KR 1899, No. 16, p. 533.

${ }^{38} \mathrm{Na}$ stoku gór tyrolskich. Obronny zameczek pod Linzem. (Z wycieczki gospodarczej) napisała C.P.Z. (Dokończenie), KR 1899, No. 17, p. 558.

${ }^{39}$ Ibidem, p. 560.

40 Tydzień spędzony w Czechach. Napisała C.P.Z., KR 1899, No. 19, p. 630.

${ }^{41}$ Ibidem, p. 632. 
Dairies located in the suburbs of Prague did not differ from technological requirements of Western civilization. The forerunner of classes in dairy was Miss Pich-Polakowa, who was recommended by the information office. She introduced Polish travelers to the world of the Czech schools and women. The latter became important heroines of Miss Plater-Zyberk's reportage, who underlined their activity in arousing national aspirations of the Czech society.

During her stay in the Czech Kingdom, Miss Plater-Zyberk visited institutions for girls in Stěžery and Louny ${ }^{42}$. The first of them, located in a newly built, impressive building, did not differ from civilizational standards from previously described German schools. Yet, it was paying more attention to the rural farm. The school in Louny was furnished less comfortably, but it had more Czech accents in its décor, as well as a more extensive farm. Both institutions, like most other, had the status of government schools and were not required to issue recommendations for work, as it was expected from the private school in Chyliczki. The problem appeared in stories of Miss Plater-Zyberk quite often, as she was dreaming about transforming Chyliczki into the first higher agricultural school for women. At the end of the $19^{\text {th }}$ century such a project had no chance of implementation, though.

Miss Plater-Zyberk spent her free time on visiting Prague. She also wrote down her impressions from the exhibition of civilizational achievements in architecture and interior design. She harshly criticized the Prague aristocrats. Women, despite access to luxurious fashion magazines, lacked chic, grace and beauty. She also disliked religious indifferentism of the Czech elites.

Connections with religion were preserved by peasants, whom the Czech emancipationists reached with the mission of civilizing. They were fighting for women's rights to education, work and prestige. Miss Plater-Zyberk's catalog of reportage's heroes consisted of women commonly known at that time ${ }^{43}$. The presentation was opened by forerunners of the emancipation, writers and social workers, Helena Nemcowa (1820-1862), Karolina Světlá (1830-1899), Honorata Zapová (1825-1856), Eliška Krásnohorská (1847-1926), an

${ }^{42}$ Tydzień spędzony w Czechach napisała C.P.Z. (Dalszy ciag), KR 1899, No. 20, p. 661.

${ }^{43}$ See P. Vošahlíková, Pozycja społeczna i prestiż kobiety pracujacej zawodowo $w$ Czechach na przełomie XIX $i$ XX wieku, [in:] Kobieta i praca. Wiek XIX $i$ XX. Zbiór studiów, vol. VI, eds A. Żarnowska, A. Szwarc, Warszawa 2000, pp. 255-266. 
editor of the female magazine "Ženské listy" that had been published since $1891^{44}$. Next to them there was an educational activist associated with the emancipation movement of women, Vojta Náprstek (1826-1894), who in 1848 ran away from reprisals to the United States and after his return founded the American Club of Ladies ${ }^{45}$. The very first initiatives of organizing rural education and folk schools came from those activists. The most interesting four economic institutions educating peasant children were recommended to Polish travelers by Pich-Polak. The first two were schools for boys and girls built in Kremsir (Kromieryż). They were run by a married couple - the wife was taking care of a boarding school for girls, the husband was responsible for educating boys from nearby villages. Miss Plater-Zyberk considered that idea of the upbringing and education, in their own social and family environment, as most appropriate for civilizing common people. She fiercely criticized attempts to emancipate people from their environment and she expected Polish landowners to show interest in the Czech model of rural economic schools.

Masculine and feminine schools in Moravia in Sohle were ideal to her $^{46}$. They were located close to each other and were the only institutions from the reportage that were functioning in a village. The building of the female school was surrounded by greenery, a large vegetable garden and farm buildings with cows kept in a cowshed that was "a real trinket in an exquisite order". The program proportionally combined the household and rural sections. The dairy was run by a teacher, a professional, with a dress and appearance of a "very well behaved person" ${ }^{47}$. A male school was run equally excellent, with a "coquetry of order". According to Miss Plater-Zyberk, complementary economic schools in Sohle were the best example of women's emancipation and modern civilization.

At the end of the presentation of the reportage by the founder of the school in Chyliczki, it is worth paying attention to her thoughts of a more general nature. She believed that first fascinations and aspirations in the pursuit of equality, stimulated and encouraged by a liberal positivism that was contesting religion, led women astray

${ }^{4}$ Tydzień spędzony $w$ Czechach napisała C.P.Z. (Dalszy ciag), KR 1899, No. 22 , pp. $725-729$.

45 Ibidem, pp. 728-729.

46 Tydzień spędzony $w$ Czechach napisała C.P.Z. (Dokończenie), KR 1899, No. 24, pp. 790-791.

47 Ibidem, p. 791. 
in the world of disturbed values and social order. A return to the village and roots meant restoring the natural order of things to man. As Miss Plater-Zyberk claimed, she only reported on the hot topic, on "observations made during the journey"48. She did not call her story a reportage, but she built it from the reported events, situations, conversations and notes, which fulfilled assumptions of that genre of writing. She admitted that during the journey she raced and chased after the topic, ready with her companion "to turn almost every stone on the road to see what was under it? ${ }^{49}$. Contemporary reporters would say that she wanted to see what was "under the surface of events" ${ }^{50}$. She gave the readers her own interpretation of them in the "Kronika Rodzinna".

She summed up her text with the point that economic schools were most necessary for women from opposite poles of the social hierarchy: rural housewives and landowners elites. For the former, they were to guarantee respect for work that should be undertaken wisely and in a modern way. For the latter, they were to involve them in a task of saving assets, prepare them for the role of wise and honest employers, as well as teach how to take on the most difficult tasks of the administrators and managers of their own families. With that message Miss Plater-Zyberk ended her reportage and said goodbye to the readers of the "Kronika Rodzinna", as she resigned from the function of the chief editor and publisher of the magazine ${ }^{51}$. She intended to continue her cooperation with it, yet, she explained her decision with an excess of duties. It could have been associated not only with the involvement in further activities of her schools, but also with the fact that she was undertaking new challenges of the $20^{\text {th }}$ century ${ }^{52}$.

48 Tydzień spędzony w Czechach..., No. 20, p. 663.

49 Wrażenia z wycieczki gospodarczej po ks. Poznańskiem przez C.P.Z., KR 1899, No. 12, p. 393.

50 M. Szczygieł, W. Toch man, Reportaż-opowieść o tym, co wydarzyło sie naprawdę, [in:] Biblia dziennikarstwa, eds A. Skworz, A. Niziołek, Kraków 2010, p. 295.

51 Stanisław Pawiński became a new editor of the magazine and Priest Hipolit Skimbrowicz, its publisher. In subsequent years, when an editorial staff of the "Kronika Rodzinna" was being changed, the magazine was transformed into a popular journal, the publisher of which since 1905 had been Priest M. Godlewski and the editor, the Catholic activist, Adam Lach Szymański, who returned to the literary ambitions of the periodical, while maintaining its religious and social character. The last issue of the "Kronika Rodzinna" was published in 1915.

${ }^{52}$ A monograph of the article's author will be devoted to the activity of Countess C. Plater-Zyberk. 


\section{Bibliography}

\section{HANDWRiting SOURCES}

The Archives of Messengers in Konstancin-Jeziorna (Archiwum Posłanniczek w Konstancinie-Jeziornie)

J. Chudzyńska, Pamiętnik, no reference number.

\section{Press}

Na stoku gór tyrolskich. Obronny zameczek pod Linzem. (Z wycieczki gospodarczej) napisała C.P.Z., "Kronika Rodzinna" 1899, No. 16, pp. 533-536.

Na stoku gór tyrolskich. Obronny zameczek pod Linzem. (Z wycieczki gospodarczej) napisała C.P.Z. (Dokończenie), "Kronika Rodzinna” 1899, No. 17, pp. 558-560.

Paryż $i$ jego okolice (Z wycieczki gospodarczej) przez C.P.Z., "Kronika Rodzinna" 1899, No. 13, pp. 435-440.

Tydzień spędzony w Czechach. Napisała C.P.Z., "Kronika Rodzinna” 1899, No. 19, pp. 630-632.

Tydzień spędzony $w$ Czechach napisała C.P.Z. (Dalszy ciag), "Kronika Rodzinna" 1899, No. 20, pp. 659-663.

Tydzień spędzony w Czechach napisała C.P.Z. (Dalszy ciag), "Kronika Rodzinna" 1899, No. 22, pp. 725-729.

Tydzień spędzony $w$ Czechach napisała C.P.Z. (Dokończenie), "Kronika Rodzinna" 1899, No. 24, pp. 789-793.

Wrażenia z wycieczki gospodarczej po ks. Poznańskim, Niemczech, Francji, Czechach. Cel podróży - Dobrojewo - Borejowice [properly Bożejowice], "Kronika Rodzinna" 1899, No. 1, pp. 15-18.

Wrażenia z wycieczki gospodarczej po ks. Poznańskim, Niemczech, Francji, Czechach. Dalszy ciag, "Kronika Rodzinna" 1899, No. 2, pp. 45-48.

Wrażenia z wycieczki gospodarczej po ks. Poznańskim, Niemczech, Francji, Czechach. Dalszy ciag, "Kronika Rodzinna" 1899, No. 3, pp. 82-85.

Wrażenia z wycieczki gospodarczej po ks. Poznańskim, Niemczech, Francji, Czechach. Przez C.P.Z. Dalszy ciag. Hanower. Hodowla drobiu, mleczarnia, "Kronika Rodzinna" 1899, No. 5, pp. 147-151.

Wrażenia z wycieczki gospodarczej po ks. Poznańskim, Niemczech, Francji, Czechach przez C.P.Z. Szkoła gospodarcza w Alzay pod Moguncja, "Kronika Rodzinna" 1899, No. 7, pp. 227-231.

Wrażenia z wycieczki gospodarczej po ks. Poznańskim, Niemczech, Francji, Czechach przez C.P.Z. (Dalszy ciag), "Kronika Rodzinna” 1899, No. 8, pp. 256-259.

Wrażenia z wycieczki gospodarczej po ks. Poznańskim, Niemczech, Francji, Czechach przez C.P.Z. (Dalszy ciag). Moguncja, "Kronika Rodzinna" 1899, No. 9, pp. 288-291.

Wrażenia $z$ wycieczki gospodarczej po ks. Poznańskim, Niemczech, Francji, Czechach przez C.P.Z. (Dalszy ciag), "Kronika Rodzinna” 1899, No. 10, pp. 328-331. 
A reportage at the end of the century... 153

Wrażenia z wycieczki gospodarczej po ks. Poznańskim, Niemczech, Francji, Czechach przez C.P.Z. (Dalszy ciag), "Kronika Rodzinna” 1899, No. 11, pp. 362-365.

Wrażenia $z$ wycieczki gospodarczej po ks. Poznańskim przez C.P.Z., "Kronika Rodzinna" 1899, No. 12, pp. 391-394.

\section{Studies}

Dzieje Śremu, ed. S. Chmielewski, Warszawa-Poznań 1972.

Chyra-Rolicz Z., Pionierki $w$ nowych zawodach na poczatku XX wieku, [in:] Kobieta i edukacja na ziemiach polskich $w$ XIX i XX w. Zbiór studiów, vol. II, part 2, eds A. Żarnowska, A. Szwarc, Warszawa 1992, pp. 221-236.

Czachowska K., Generałowa Jadwiga Zamoyska (1831-1923). Życie i dzieło, Poznań 2011.

Górski T., Plater-Zyberk Cecylia, [in:] Polski słownik biograficzny, vol. XXVI, Kraków 1981, pp. 693-694.

Kamiński D., Barbara z Mańkowskich Kwilecka-wybitna Wielkopolanka, "Wiadomości Ziemiańskie" 2017, No. 71, pp. 82-88.

Kobieta i media. Studia z dziejów emancypacji kobiet, eds P. Perkowski, T. Stegner, Gdańsk 2009.

Kostrzewska M.E., Szkolnictwo gospodarczo-rolnicze ziemianek Królestwa Polskiego na przełomie XIX i XX w. Między tradycja a nowoczesnościa, [in:] $Z$ dziejów polskiej kultury i oświaty od średniowiecza do początków XX wieku, eds K. Jakubiak, T. Maliszewski, Kraków 2010, pp. 145-161.

Kostrzewska M.E., Ziemianki Królestwa Polskiego a gospodarka. Koncepcje i empiria (przełom wieków XIX i XX), "Studia Maritima" [Szczecin] 2015, vol. XXVIII, eds Z. Anusik, R. Gaziński, pp. 295-315.

Lesisz B., Polskie czasopisma religijno-społeczne w XIX w., Warszawa 1988.

Mattelart A., Mattelart M., Teoria komunikowania, Warszawa 2001.

Mazurek H.M., Powstanie i rozwój ukrytych zgromadzeń bł. Honorata Koźmińskiego w latach 1874-1908, Sandomierz 2009.

Molik W., Przekształcanie sie wielkopolskiego szlachcica w ziemianina- uspołecznionego farmera $w$ XIX $i$ na poczatku XX w., [in:] Ziemiaństwo wielkopolskie. W kręgu arystokracji, ed. A. Kwilecki, Poznań 2004, pp. 24-44.

Molik W., Ziemianki wielkopolskie $w$ codziennych zajeciach gospodarczych $i w$ pracy społecznej $w$ drugiej połowie XIX i na poczatku XX wieku, [in:] Kobieta i kultura życia codziennego wiek XIX i XX. Zbiór studiów, vol. V, eds A. Żarnowska, A. Szwarc, Warszawa 1997, pp. 181-190.

Sikorska-Kowalska M., Kwestia kobieca $w$ świetle programu społecznego "Kroniki Rodzinnej” Aleksandry Borkowskiej (1867-1872), "Acta Universitatis Lodziensis", Folia Historica 61, 1998, pp. 17-32.

Szczygieł M., Tochman W., Reportaż - opowieść o tym, co wydarzyło się naprawdę, [in:] Biblia dziennikarstwa, eds A. Skworz, A. Niziołek, Kraków 2010, pp. 294-306.

Vošahlikková P., Pozycja społeczna i prestiż kobiety pracujacej zawodowo w Czechach na przełomie XIX $i$ XX wieku, [in:] Kobieta i praca. Wiek XIX i XX. Zbiór studiów, vol. VI, eds A. Żarnowska, A. Szwarc, Warszawa 2000, pp. 255-266. 
Wojtak M., Gatunki prasowe, Lublin 2004.

Ziemiaństwo na Lubelszczyźnie IV. Ziemianie $w$ podróży, vol. I-II, ed. H. Łaszkiewicz, Lublin 2010.

Ewelina Maria Kostrzewska

\title{
Reportaż na koniec wieku. Europejskie podróże gospodarcze Cecylii hr. Plater-Zyberkówny w świetle „Kroniki Rodzinnej” (1899 r.)
}

\begin{abstract}
A rtykuł przygotowany został na podstawie „Kroniki Rodzinnej”, dwutygodnika wydawanego od 1867 r. w Warszawie. Adresowany do ziemiaństwa oraz inteligencji miał charakter literacko-społeczny i pamiętnikarsko-podróżniczy, często podejmował sprawy tzw. kwestii kobiecej. W czasie swojego istnienia zachodziły $\mathrm{w}$ nim przekształcenia programowe, a po wyciszeniu sporów ideologicznych w latach osiemdziesiatych XIX w. redakcja skupiała uwagę na sprawach domowych $i$ wychowawczych. Płynąc $z$ umiarkowanym nurtem ruchu równouprawnienia kobiet, propagowała ich zawodowe wykształcenie oraz aktywność.

W 1899 r. naczelna redaktorka i wydawczynia pisma została Cecylia hr. Plater-Zyberkówna, która w swoich poglądach asymilowała ziemiańskie, zachowawcze ideały $z$ inteligenckim modelem otwartego katolicyzmu. W okresie jej prawie rocznej kadencji „Kronikę Rodzinną” przekształcano w popularne „Czasopismo dla Rodzin Katolickich”. Sama redaktorka zaś zainaugurowała i zamknęła pełnienie swoich funkcji drukowanym w odcinkach reportażem podróżniczym.

Taka nowoczesna forma dziennikarskiego sprawozdania wchodziła $\mathrm{w}$ trudno dostępny dla kobiet świat mediów, samodzielnych, szybkich podróży i pracy zawodowej. Sprowadzając do wspólnego mianownika poszukiwania w Europie żeńskich szkół gospodarczych, zdawała relację $z$ ich cywilizacyjnej kondycji. W nasyconych religijna aksjologią opisach przedstawiała czytelnikom własne refleksje i społeczne konteksty emancypacji kobiet.

W poincie podróżniczej relacji powracała na polski grunt $z$ idea solidaryzmu społecznego; pogodzenia aspiracji kobiet $z$ religią. Więź społeczna w sposób szczególny łączyć miała kobiety z ziemiańskich elit i chłopskiej wsi, a szkoły gospodarcze otwierać im pola aktywności i pracy. W myśl regul prasowego reportażu opowieść Plater-Zyberkówny odsłaniała europejska rzeczywistość końca XIX w. w jej subiektywnych obrazach widzianych z perspektywy arystokratki i naczelnej katolickiej „Kroniki Rodzinnej”.
\end{abstract}

Słowa kluczowe: czasopisma katolickie, „Kronika Rodzinna”, reportaż, Cecylia hr. Plater-Zyberkówna, prasa Królestwa Polskiego, podróże, szkoły gospodarcze, Europa. 